\title{
Total pain in a patient with lung cancer diagnosis
}

\section{Abstract}

Pain is experienced by most cancer patients. According to the definition of the International Society for the Study of Pain (IASP), pain is an unpleasant sensory and emotional experience associated with, or resembling that associated with, actual or potential tissue damage. This very "medical" definition indicates that pain is a mental, subjective, sensual, emotional, and unpleasant phenomenon. In palliative care, there is often a need for a better and deeper understanding of what "total" pain can be. The case of a young patient with lung cancer diagnosis presented an opportunity to describe characteristics of such pain, which encompasses physical, mental, social and spiritual suffering.

Palliat Med Pract 2020; 14, 3: 219-222

Key words: total pain, clinical communication, lung cancer

\section{Introduction}

Cicely Saunders introduced the concept of total pain into palliative care, to highlight the multidimensional nature of suffering and the fact that it can come from physical, mental, social and spiritual dimensions. The intensity of pain can be influenced by anything that is related to a given patient. Things such as concern about family or finances, fear of pain, death, feeling of helplessness, anger at fate for sending the illness, insomnia often intensify the pain resulting from somatic disease but affect individuals to a different degree [1]. There are various factors, including discomfort, fatigue, anxiety, anger, sadness, social isolation, which lead to a decreased threshold of pain. There are also factors such as getting enough sleep, companionship, understanding, physical activity, reduced anxiety, which lead to an increased threshold of pain [2]. Pain management according to the recommendations of the World Health Organization allows to obtain a successful analgesic effect in about $70-90 \%$ of cancer patients $[3,4]$. The fact that in clinical practice about half of the patients still suffer from pain indicates the need for attentive diagnostics, especially for a comprehensive assessment of the needs and circumstances of the patient and his/her relatives. It is worth remembering that young people with cancer have slightly different needs than children or the elderly. There is a problem of changing life plans, and various types of limitations and reactions of other people in the workplace, or the fear of relapse. Successful psychological interventions facilitate the struggle with cancer [5].

Presented below is a case that illustrates the nature of multidimensional pain in a young woman with lung cancer who, during the progression of the disease, reported increasing pain, periodically intensifying and poorly responding to treatment based on the use of several opioid analgesics and analgesic adjuvants.

\section{Case presentation}

In August 2008, a 36-year-old woman came to the Regional Centre of Pulmonology (KPCP) in By-

Address for correspondence:

Agnieszka Nowakowska-Arendt

Palliative Care Department, Nicolaus Copernicus University in Toruń,

Collegium Medicum in Bydgoszcz

Skłodowskiej-Curie 9, 85-094 Bydgoszcz

e-mail: agnieszka.arendt@cm.umk.pl

Palliative Medicine in Practice 2020; 14, 3, 219-222

Copyright (c) Via Medica, ISSN 2545-0425

DOI: 10.5603/PMPI.2020.0021 
dgoszcz. On admission, she reported a dry cough, exercise-induced dyspnoea and pain in the left half of the chest that intensified by deep breathing. The patient had history of thyroid goitre, taking Levothyroxine at a dose of $1 \times 100 \mathrm{ug}$. The patient did not smoke herself, but while at home she was a passive smoker (the patient's father smoked). Moreover, on the farm where she lived, there was a farm building with an asbestos roof covering.

On admission, physical examination and chest $X$-ray revealed the presence of fluid in the left pleural cavity. A diagnostic and decompression puncture was performed, obtaining a bloody fluid, which was sent for further examination. Laboratory, endoscopic and imaging diagnostics were performed. Due to ambiguous results of cytological examination of pleural fluid and the need for further differential diagnosis between lung adenocarcinoma and pleural mesothelioma, a videothoracoscopy was scheduled. During the examination, the fluid was evacuated from the pleural cavity and numerous small mucous lesions were visible on the surface of the pleura, lung, diaphragm and pericardial sac, from which samples were taken for histopathological evaluation. The diagnosis of poorly differentiated lung adenocarcinoma was established. Genetic testing was also carried out, but yielded a negative result in terms of mutations in the epidermal growth factor receptor (EGFR) gene.

The patient was qualified for chemotherapy, including four cycles of standard chemotherapy in line with the PE protocol (cisplatin + ethoposide), according to the British Columbia Cancer guidelines. The patient completed her treatment in November 2013. Further follow-up visits were carried out at the Lung Disease Clinic of the KPCP in Bydgoszcz. Due to a positive result for an ALK gene (anaplastic lymphoma kinase) rearrangement the patient was referred for further treatment at the Medical University of Gdańsk. A gradual progression of the disease was observed with the spread to the liver, spleen and skeletal system (ribs, body of sternum and vertebral body of the thoracic spine). In January 2015, the patient underwent a palliative brain radiotherapy due to metastases. In September 2015, the patient underwent a hysterectomy with appendages, appendectomy, omentectomy, and excision of obturator lymph nodes due to spread to the reproductive organ at the Department of Obstetrics, Women's Diseases, and Gynaecological Oncology of the University Hospital No. 2 in Bydgoszcz. With the progression of the illness, pain was intensified, mainly in the left half of the chest, periodically also in other locations. She experienced pain of mixed origin: somatic, visceral and neuropathic. Despite the progress of the illness, the chemotherapy was continued.
During follow-up visits at the Lung Disease Clinic, the patient reported increasing severity of pain. The patient lived with an extended family, including her husband and two teenage children - daughter and son - and her parents. The patient's family has been running a farm for generations. The patient was a stay-at-home mother and for many years helped her parents on the farm.

The analgesic treatment was initiated according to the three-step analgesic ladder. To begin with, she was given ketoprofen at a dose of $200 \mathrm{mg}$ per day, in divided doses, in combination with tramadol - initially $200 \mathrm{mg}$ per day and then the dose was increased to $400 \mathrm{mg}$ per day. However, over a period of several months pain in the left half of the chest was becoming stronger, the patient estimated it at $8-9 / 10$ according to the NRS. Tramadol was replaced with immediate-release morphine at the initial dose of $5 \mathrm{mg}$ every 4 hours. The treatment with ketoprofen was continued, and gabapentin at a dose of $2 \times 300 \mathrm{mg}$ was included due to neuropathic pain. Constipation prevention was also included implemented. Despite the gradual increase of the morphine dose, only a partial analgesic effect was observed (NRS 7). Due to persistent constipation, morphine was replaced with an equivalent dose of oxycodone with naloxone, which was gradually increased to $60 \mathrm{mg}$ of oxycodone $+30 \mathrm{mg}$ of naloxone per day. Due to the lack of immediate-release morphine effectiveness, transmucosal fentanyl, at the initial dose of $50 \mu \mathrm{g}$ later increased to $100 \mu \mathrm{g}$, was used to treat breakthrough pain which led to a satisfactory analgesic effect. The treatment with coanalgesics was also adjusted. The dose of gabapentin was increased to $400 \mathrm{mg}$ per day, followed by venlafaxin $75 \mathrm{mg}$ once per day and amitriptyline $10 \mathrm{mg}$ per night. Despite the treatment, the analgesic effect was unsatisfactory (NRS 5).

While the patient was hospitalised at the Lung Disease and Lung Cancer Department, during a conversation the attending physician observed that she experienced significant anxiety. She asked, "why she got sick if she never smoked and only her father and brothers smoked".

The patient was referred to a Palliative Care Clinic for consultation and adjustment of symptomatic treatment. Due to mixed pain with a distinct neuropathic component in addition to previously mentioned medications, the patient was given methadone at a dose of $3 \mathrm{mg}$ every 8 hours and additional $3 \mathrm{mg}$ in case of pain increase, but not more often than every 6 hours. The dose of the medication was increased to $5 \mathrm{mg}$ every 8 hours after the next visit. Due to the lack of a satisfactory analgesic effect despite adjustment 
of analgesic treatment, the patient was referred to an Inpatient Hospice.

During the first day of her stay, during a conversation with a psychologist, the patient expressed great concern about the future of her family, her husband and two children. The patient felt helpless when she was unable to keep helping her parents on the farm. Moreover, the patient's parents announced that after her death, it would be impossible for them to continue living with their son-in-law and grandchildren. The prospect of her loved ones losing their home increased the pain felt by the patient. For this reason, it was necessary to talk to the patient's husband and parents. In the next stage of treatment, the patient was under the care of an interdisciplinary team consisting of doctors, a physiotherapist and a psychologist - the latter offered support to the patient and her family. We managed to encourage the patient's husband, children and parents to cooperate. After the patient's parents attended several sessions with a psychologist, her anxiety was alleviated and her pain was less severe; over the period of several days and without adjusting medication doses, her average pain intensity decreased from 9 to $2-3$ according to the NRS. The restoration of hope that her husband and children will be able to continue living safely in her parents' home and good communication within the family also led to the restoration of mutual trust and a sense of community, which proved to be an important part of the holistic management of the multidimensional pain and suffering of the patient.

\section{Discussion}

The presented case of a young patient indicates that pain should be assessed and treated comprehensively taking into account the patient's physical, psychological, social and spiritual well-being. In addition, the course of the illness and the daily functioning of cancer patients may be affected by various factors such as their age and living standards.

Green and Hart-Johnson indicated that younger patients complained more often about more severe pain. Moreover, according to the authors, the oldest patients, in the group over 60 years of age, functioned better in emotional and cognitive terms, as compared to younger patients under 40 [6]. Sugden presented the multifaceted nature of total pain based on two cases. The need for effective communication with the patient and the multidisciplinary approach of the team to the reported somatic complaints was emphasised. [7].

The presented case of the patient indicates that the physical dimension of pain should not be consid- ered in isolation from the mental, social and spiritual suffering experienced by patients. The psychological dimension is often referred to as the emotional element of total pain $[8,9]$. The patient's emotional pain was expressed through feelings such as powerlessness, helplessness and fear. The social component was also important. Fear of the future of the family and their home, intensified the patient's ailments. The spiritual pain was expressed by the thoughts, "why did I get sick, why it happened to me".

Members of the interdisciplinary palliative care team patiently listened to all complaints and concerns reported by the patient, providing psychological support. The patient's family was included in the care and encouraged to see a psychologist. The family was presented with the patient's feelings related to the illness, its progress and fears about the future of her loved ones. During previous visits to the Clinic, the patient was not asked if she wanted to be alone during the visit; she was always accompanied by her husband. This did not provide an opportunity for an intimate conversation in which the patient could open up and reveal the causes of her general discomfort and multidimensional suffering. Despite concerns, including the risk of drug interactions, doctors used painkillers and coanalgesics in treatment. The patient's case indicates the important role of proper communication with patients and attentive listening, without which it is impossible to diagnose and appropriately manage multidimensional pain $[10,11]$.

\section{Conclusions}

Total pain is often found in cancer patients. The alleviation of mental, social, and spiritual aspects of suffering is as important as the treatment of physical pain $[12,13]$. Such an approach is beneficial in terms of more effective pain management, improved quality of life and increased patient satisfaction [14-16]. The concept of total pain should be taken into account at the stage of diagnosis and treatment of cancer patients [17]. An interdisciplinary approach, ability to communicate properly and involvement of loved ones in the treatment process are of vital importance [18].

\section{Declaration of conflict of interests}

The authors declare that there is no conflict of interest.

\section{Funding}

None declared.

No identifiable information about the patient is included in the manuscript. 


\section{References}

1. Global year against cancer pain: October 2008-October 2009: Total cancer pain. https://www.iasp-pain.org/GlobalYear/CancerPain (20 October 2013).

2. MacLeod R. Total pain-physical, psychological and spiritual. Goodfellow Symposium. 2007. http://www.fmhs.auckland. ac.nz/soph/centres/goodfellow/_docs/total_pain_handout. pdf (20 October 2013).

3. PTBB - Farmakoterapia bólu u chorych na nowotwory.

4. Wytyczne WHO dotyczące leczenia bólu.

5. Zebrack BJ. Psychological, social, and behavioral issues for young adults with cancer. Cancer. 2011; 117(10 Suppl): 2289-2294, doi: 10.1002/cncr.26056, indexed in Pubmed: 21523748.

6. Green CR, Hart-Johnson T. Cancer pain: an age-based analysis. Pain Med. 2010; 11(10): 1525-1536, doi: 10.1111/j. 1526-4637.2010.00957.x, indexed in Pubmed: 21199305.

7. Sugden C. Total pain: a multidisciplinary approach. Health and Social Care Chaplaincy. 2013; 4(2): 2-7, doi: 10.1558/hscc.v4i2.2.

8. Mehta A, Chan L. Understanding of the Concept of „Total Pain". Journal of Hospice \& Palliative Nursing. 2008; 10(1): 26-32, doi: 10.1097/01.njh.0000306714.50539.1a.

9. Syrjala $\mathrm{KL}$, Jensen MP, Mendoza ME, et al. Psychological and behavioral approaches to cancer pain management. J Clin Oncol. 2014; 32(16): 1703-1711, doi: 10.1200/JCO.2013.54.4825, indexed in Pubmed: 24799497.

10. Silverman J, Kurtz S, Draper J. Skills for Communicating with Patients. 2016, doi: 10.1201/9781910227268.

11. Shindul-Rothschild J, Flanagan J, Stamp KD, et al. Beyond the Pain Scale: Provider Communication and Staffing Predictive of Patients' Satisfaction with Pain Control.
Pain Manag Nurs. 2017; 18(6): 401-409, doi: 10.1016/j. pmn.2017.05.003, indexed in Pubmed: 28843634.

12. Reddy A, Hui D, Bruera E. A Successful Palliative Care Intervention for Cancer Pain Refractory to Intrathecal Analgesia. Journal of Pain and Symptom Management. 2012; 44(1): 124-130, doi: 10.1016/j.jpainsymman.2011.07.010.

13. Wachholtz AB, Fitch CE, Makowski S, et al. A Comprehensive Approach to the Patient at End of Life: Assessment of Multidimensional Suffering. South Med J. 2016; 109(4): 200-206, doi: 10.14423/SMJ.0000000000000439, indexed in Pubmed: 27043799.

14. Palliative TrR, Kongsgaard U, Kaasa S, et al. Palliative Treatment of Cancer-Related Pain [Internet]Editors, Kongsgaard U, Kasa S, Dale O, Ottesen S, Nordøy T, Hessling SE, von Hofacker S, Bruland ØS, Lyngstadaas A.

15. Panikulam A. Total pain management. Indian J Palliat Care. 2011; 17(Suppl): S68-S69, doi: 10.4103/0973-1075.76246, indexed in Pubmed: 21811375.

16. Brant J. Holistic Total Pain Management in Palliative Care: Cultural and Global Considerations. Palliative Medicine and Hospice Care - Open Journal. 2017; SE(1): S32-S38, doi: 10.17140/pmhcoj-se-1-108.

17. Silbermann $M$, Pitsillides $B, A l-A l f i ~ N$, et al. Multidisciplinary care team for cancer patients and its implementation in several Middle Eastern countries. Ann Oncol. 2013; 24 Suppl 7: vii41-vii47, doi: 10.1093/annonc/mdt265, indexed in Pubmed: 24001762.

18. Wachholtz AB, Fitch CE, Makowski S, et al. A Comprehensive Approach to the Patient at End of Life: Assessment of Multidimensional Suffering. South Med J. 2016; 109(4): 200-206, doi: 10.14423/SMJ.0000000000000439, indexed in Pubmed: 27043799. 


\section{Ból totalny u chorej z rozpoznaniem raka płuca}

Artykuł jest tłumaczeniem pracy: Nowakowska-Arendt A., Graczyk M., Gęsińska H., Krajnik M., Total pain in a patient with lung cancer diagnosis. Palliat. Med. Pract. 2020 tom 14, nr 3: 219-222.

Należy cytować wersję pierwotną.

\section{Streszczenie}

Ból jest objawem towarzyszącym większości chorych na nowotwory. Zgodnie z definicją Międzynarodowego Towarzystwa Badania Bólu (IASP) ból to nieprzyjemne, zmysłowe i emocjonalne przeżycie towarzyszące istniejącemu lub zagrażającemu uszkodzeniu tkanki bądź jedynie odnoszone do takiego uszkodzenia. Ta bardzo „medyczna” definicja wskazuje na fakt, że ból jest zjawiskiem psychicznym, subiektywnym, jednocześnie zmysłowym i emocjonalnym, nieprzyjemnym. W opiece paliatywnej nierzadko istnieje potrzeba szerszego i głębszego dostrzegania, czym może być ból „totalny”. Na przykładzie młodej chorej z rozpoznaniem raka płuca przedstawiono charakterystyczne cechy takiego bólu, który obejmuje cierpienie fizyczne, psychiczne, społeczne i duchowe.

Palliat Med Pract 2020; 14, 3: 223-226

Słowa kluczowe: ból totalny, komunikacja kliniczna, rak płuca

\section{Wstęp}

Cicely Saunders wprowadziła do opieki paliatywnej pojęcie bólu totalnego dla podkreślenia wielowymiarowości cierpienia i faktu, że jego źródło może pochodzić z wymiaru fizycznego, psychicznego, społecznego i duchowego. Na intensywność odczuwania dolegliwości bólowych wpływ może mieć wszystko, co jest związane z danym pacjentem. Troska o rodzinę, finanse, lęk przed bólem, śmiercią, uczucie bezradności, złość na los, który zesłał chorobę, bezsenność, często nasila ból wynikający z choroby somatycznej i to w sposób zróżnicowany, zależny od indywidualnego człowieka [1]. Istnieją różne czynniki, między innymi takie jak dyskomfort, zmęczenie, lęk, złość, smutek, izolacja społeczna, które powodują obniżenie progu bólu. Istnieją również czynniki, takie jak właściwy sen, towarzystwo, zrozumienie, aktywność fizyczna, zmniejszenie lęku, które próg bólu podwyższają [2]. Postępowanie przeciwbólowe zgodne z rekomendacjami Światowej Organizacji Zdrowia pozwala uzyskać skuteczny efekt przeciwbólowy u około 70-90\% leczonych na nowotwory [3, 4]. Fakt, że w praktyce klinicznej nadal około połowa pacjentów cierpi z powodu bólu, wskazuje na konieczność uważności w jego diagnostyce, a zwłaszcza konieczności całościowej oceny potrzeb i sytuacji chorego i jego bliskich. Warto pamiętać, że młodzi chorzy na nowotwory mają nieco inne potrzeby niż dzieci czy osoby starsze. Pojawia się problem modyfikacji planów życiowych, różnego typu ograniczeń i reakcji innych osób w miejscu pracy czy obawa przed nawrotem choroby. Udane interwencje psychologiczne ułatwiają zmaganie się z chorobą nowotworową [5].

Adres do korespondencji:

Agnieszka Nowakowska-Arendt

Katedra Opieki Paliatywnej, Uniwersytet Mikołaja Kopernika w Toruniu,

Collegium Medicum w Bydgoszczy

ul. Skłodowskiej-Curie 9, 85-094 Bydgoszcz

e-mail: agnieszka.arendt@cm.umk.pl 
Poniżej przedstawiono przypadek przybliżający znaczenie wielowymiarowości bólu u młodej kobiety chorej na raka płuca, która w trakcie progresji choroby nowotworowej podawała narastające dolegliwości bólowe, nasilające się okresowo, a słabo reagujące na prowadzone leczenie oparte na stosowaniu kilku analgetyków opioidowych i adjuwantów analgetycznych.

\section{Opis przypadku}

W sierpniu 2013 roku do Kujawsko-Pomorskiego Centrum Pulmonologii (KPCP) w Bydgoszczy zgłosiła się 36-letnia pacjentka. Przy przyjęciu zgłaszała suchy kaszel, duszność wysiłkową i ból lewej połowy klatki piersiowej nasilający się przy głębokim oddychaniu. W wywiadzie podawała wole tarczycy, przyjmowała lewotyroksynę w dawce $1 \times 100 \mu \mathrm{g}$. Chora nie paliła papierosów, natomiast $w$ domu rodzinnym była biernym palaczem (palit ojciec pacjentki). Ponadto, w gospodarstwie, w którym mieszkała, na budynku gospodarczym znajdował się dach pokryty azbestem.

Przy przyjęciu w badaniu fizykalnym i w badaniu radiologicznym klatki piersiowej stwierdzono obecność płynu w lewej jamie opłucnej. Wykonano punkcję diagnostyczno-odbarczającą, uzyskując krwisty płyn, który wysłano do dalszych badań. Przeprowadzono diagnostykę laboratoryjną, endoskopową i obrazową. Ze względu na niejednoznaczny wynik badania cytologicznego płynu z jamy opłucnej i konieczność dalszej diagnostyki różnicowej pomiędzy rakiem gruczołowym płuca a międzybłoniakiem opłucnej zaplanowano wideotorakoskopię. Podczas badania ewakuowano płyn z jamy opłucnowej i uwidoczniono na powierzchni opłucnej, płuca, przeponie i w worku osierdziowym liczne zmiany drobnoguzkowe, z których pobrano wycinki do oceny histopatologicznej. Ustalono rozpoznanie raka gruczołowego niskozróżnicowanego płuca. Przeprowadzono również diagnostykę genetyczną, uzyskując ujemny wynik mutacji genu receptora naskórkowego czynnika wzrostu (EGFR, epidermal growth factor receptor).

Chorą zakwalifikowano do chemioterapii, podano 4 cykle chemioterapii standardowej według schematu PE (cisplatyna + etopozyd), zgodnie z wytycznymi British Columbia Cancer. Chora zakończyła leczenie w listopadzie 2013 roku. Dalsze kontrole odbywały się w ramach Poradni Chorób Płuc KPCP w Bydgoszczy. Z powodu dodatniego wyniku rearanżacji genu ALK (kinazy chłoniaka anaplastycznego) chorą skierowano do dalszego leczenia w Gdańskim Uniwersytecie Medycznym. Obserwowano stopniową progresję choroby z rozsiewem do wątroby, śledziony i układu kostnego (żebra, trzonu mostka i kręgosłupa piersiowego). W styczniu 2015 roku chorą poddano paliatywnej radioterapii mózgowia z powodu przerzutów. We wrześniu 2015 roku w Klinice Położnictwa, Chorób Kobiecych i Ginekologii Onkologicznej Szpitala Uniwersyteckiego $\mathrm{nr} 2 \mathrm{w}$ Bydgoszczy wykonano zabieg histerektomii z przydatkami, appendektomii, omentektomii i usunięcia węztów chłonnych zasłonowych z powodu rozsiewu do narządu rodnego. Wraz z progresją choroby nasilały się dolegliwości bólowe, zlokalizowane głównie w lewej połowie klatki piersiowej, okresowo również w innych lokalizacjach. Ból miał charakter mieszany: somatyczny, trzewny i neuropatyczny. Pomimo postępu choroby kontynuowano chemioterapię.

Podczas kontrolnych wizyt w Poradni Chorób Płuc pacjentka zgłaszała nasilenie dolegliwości bólowych. Chora mieszkała w domu wielopokoleniowym z mężem i dwójką nastoletnich dzieci, córką i synem, oraz swoimi rodzicami. Rodzina pacjentki od pokoleń prowadziła gospodarstwo rolne. Chora od wielu lat zajmowała się domem i pomagała rodzicom w gospodarstwie.

Leczenie przeciwbólowe rozpoczęto zgodnie z trójstopniową drabiną analgetyczną. Początkowo do leczenia włączono ketoprofen w dawce $200 \mathrm{mg} /$ dobę, w dawkach podzielonych, w połączeniu z tramadolem - początkowo $200 \mathrm{mg} /$ dobę, a następnie dawkę zwiększono do $400 \mathrm{mg} /$ dobę. Jednak w okresie kilku miesięcy nastąpiło nasilenie dolegliwości bólowych lewej połowy klatki piersiowej, oceniane według pacjentki na 8-9/10 według skali NRS (Numerical Rating Scale). Zastąpiono tramadol morfiną o natychmiastowym uwalnianiu w dawce początkowej $5 \mathrm{mg}$ co 4 godziny. Kontynuowano leczenie ketoprofenem, włączono gabapentynę w dawce $2 \times 300 \mathrm{mg}$, z powodu komponentu neuropatycznego bólu. Wdrożono także profilaktykę zaparć. Pomimo stopniowego zwiększania dawki morfiny, zaobserwowano częściową efekt analgetyczny (NRS 7). Z uwagi na uporczywe zaparcia zamieniono morfinę na równoważną dawkę oksykodonu z naloksonem, którą stopniowo zwiększano do $60 \mathrm{mg}$ oksykodonu $+30 \mathrm{mg}$ naloksonu na dobę. Ze względu na brak efektu morfiny o natychmiastowym uwalnianiu, w leczeniu bólu przebijającego stosowano fentanyl przezśluzówkowy, początkowo $50 \mu \mathrm{g}$, zwiększony do $100 \mu \mathrm{g}$, uzyskując zadowalający efekt analgetyczny. Modyfikowano również leczenie koanalgetykami. Zwiększano dawkę gabapentyny do $400 \mathrm{mg} /$ dobę, a następnie włączono wenlafaksynę w dawce $75 \mathrm{mg}$ raz na dobę i amitryptylinę $w$ dawce $10 \mathrm{mg}$ na noc. Pomimo stosowanego leczenia efekt przeciwbólowy był niezadowalający (NRS 5).

W czasie pobytu na Oddziale Chorób Płuc i Leczenia Raka Płuc, podczas rozmowy lekarz prowadzący zaobserwował znaczny niepokój pacjentki. Zadawała 
pytania: „Dlaczego ona zachorowała, skoro nigdy nie paliła papierosów, papierosy palił ojciec i bracia pacjentki".

Chora została skierowana do Poradni Medycyny Paliatywnej celem konsultacji i modyfikacji leczenia objawowego. U pacjentki z uwagi na ból mieszany z wyraźnym komponentem neuropatycznym dołączono do wcześniej stosowanego leczenia, metadon w dawce $3 \mathrm{mg}$ co 8 godzin i 3 mg dodatkowo w razie nasilenia bólu, jednak nie częściej niż co 6 godzin. Dawkę leku przy kolejnej wizycie zwiększono do $5 \mathrm{mg}$ co 8 godzin. Mimo modyfikacji leczenia przeciwbólowego, z uwagi na brak zadowalającego efektu analgetycznego, chorą skierowano do Hospicjum Stacjonarnego.

Podczas pierwszego dnia pobytu $\mathrm{w}$ rozmowie z psychologiem chora ujawniła znaczną obawę o dalsze losy swojej rodziny, męża i dwójkę dzieci. Chora czuła się bezradna w sytuacji niemożności dalszej pomocy rodzicom w gospodarstwie. Ponadto, rodzice pacjentki zapowiedzieli, że po jej śmierci dalsze mieszkanie z nimi zięcia i wnuków będzie niemożliwe. Perspektywa, że utracą możliwość dalszego zamieszkiwania powodowała u pacjentki nasilenie bólu. $Z$ tego powodu konieczna była rozmowa z mężem i rodzicami pacjentki. W dalszym etapie leczenia chora objęta była opieką zespołu interdyscyplinarnego składającego się z lekarzy, fizjoterapeuty i psychologa - ten ostatni zaproponował wsparcie pacjentce i jej rodzinie. Udało się zaprosić do współpracy męża, dzieci i rodziców pacjentki. Po kilku spotkaniach rodziców pacjentki z psychologiem zaobserwowano złagodzenie lęku i mniejsze natężenie bólu u chorej, w okresie kilku dni bez modyfikacji dawek leków średnie natężenie bólu uległo obniżeniu z 9 do 2-3 według NRS. Odzyskanie przez chorą nadziei, że mąż i dzieci będą mogli bezpiecznie nadal mieszkać w domu rodziców i dobra komunikacja w rodzinie spowodowały odbudowanie wzajemnego zaufania i poczucie wspólnoty, co okazało się istotną częścią całościowego postępowania w wielowymiarowym bólu i cierpieniu chorej.

\section{Dyskusja}

Zaprezentowany przypadek młodej chorej wskazuje, że ból należy oceniać i leczyć w sposób całościowy, uwzględniając sferę fizyczną, psychosocjalną i duchową pacjenta. Ponadto, na przebieg choroby i codzienne funkcjonowanie chorych na nowotwory mogą wpływać różne czynniki, takie jak wiek i sytuacja życiowa pacjentów.

Green i Hart-Johnson wskazali, że młodsi pacjenci skarżyli się częściej na bardziej nasilone dolegliwości bólowe. Ponadto według autorów najstarsi pacjenci, w grupie powyżej 60 lat, lepiej funkcjonowali w wy- miarze emocjonalnym i poznawczym, w porównaniu z młodszymi pacjentami w wieku poniżej 40 lat [6]. Sugden przedstawił wielopłaszczyznowy charakter bólu totalnego na podstawie dwóch przypadków. Podkreślono potrzebę skutecznej komunikacji z pacjentem i wielodyscyplinarne podejście zespołu do zgłaszanych dolegliwości somatycznych. [7].

Przedstawiony przypadek chorej wskazuje, że fizyczny wymiar bólu nie powinien być rozpatrywany w oderwaniu od cierpienia psychicznego, społecznego i duchowego, którego doświadczają pacjenci. Wymiar psychologiczny jest często określany jako emocjonalny element bólu totalnego $[8,9]$. Ból emocjonalny pacjentki wyrażany był przez uczucia, takie jak bezsilność, bezradność i strach. Komponent społeczny również był istotny. Obawa o dalsze losy rodziny, jej miejsca zamieszkania, nasilały dolegliwości pacjentki. Ból duchowy wyrażony był myślą „dlaczego ja zachorowałam, dlaczego mnie to spotkało".

Członkowie interdyscyplinarnego zespołu opieki paliatywnej cierpliwie słuchali wszystkich zgłaszanych przez pacjentkę dolegliwości i obaw, udzielając wsparcia psychologicznego. Rodzina pacjentki została włączona do opieki i zachęcona do współpracy z psychologiem. Rodzinie przedstawiono odczucia pacjentki związane z chorobą, jej postępem i obawami o dalszy los najbliższych. Podczas odbywanych wcześniej wizyt w Poradni nie zapytano chorej, czy chce podczas wizyty być sama, zawsze towarzyszył jej mąż. Nie dawało to możliwości intymnej rozmowy, w której chora mogłaby się otworzyć i ujawnić przyczyny jej ogólnego złego samopoczucia i wielowymiarowego cierpienia. Lekarze, pomimo obaw związanych między innymi z ryzykiem interakcji lekowych, stosowali leki przeciwbólowe i koanalgetyki. Prezentacja chorej wskazuje jak istotną rolę odrywa właściwa komunikacja z chorymi i uważność słuchania, bez której nie jest możliwe rozpoznanie wielowymiarowego bólu i zastosowanie odpowiedniego postępowania terapeutycznego $[10,11]$.

\section{Wnioski}

Ból totalny występuje dość często u chorych na nowotwory. Łagodzenie psychicznych, społecznych i duchowych wymiarów cierpienia jest równie ważne, jak leczenie bólu fizycznego $[12,13]$. Takie podejście przynosi korzyści w postaci skuteczniejszego leczenia bólu, poprawy jakości życia i zwiększa satysfakcję pacjenta [14-16]. Pojęcie bólu totalnego powinno być uwzględniane na etapie diagnozowania i w leczeniu chorych na nowotwory [17]. Podstawową rolę odgrywa podejście interdyscyplinarne, umiejętność właściwej komunikacji i włączenie osób bliskich do współudziału w procesie leczenia chorych [18]. 


\section{Deklaracja konfliktu interesów}

Autorzy oświadczają, że nie występuje konflikt interesów.

\section{Finansowanie}

To badanie nie zostało sfinansowane.

Manuskrypt nie zawiera informacji, które mogłyby umożliwić identyfikację pacjentki.

\section{References}

1. Global year against cancer pain: October 2008-October 2009: Total cancer pain. https://www.iasp-pain.org/GlobalYear/CancerPain (20 October 2013).

2. MacLeod R. Total pain-physical, psychological and spiritual. Goodfellow Symposium. 2007. http://www.fmhs.auckland. ac.nz/soph/centres/goodfellow/_docs/total_pain_handout. pdf (20 October 2013).

3. PTBB - Farmakoterapia bólu u chorych na nowotwory.

4. Wytyczne WHO dotyczące leczenia bólu.

5. Zebrack BJ. Psychological, social, and behavioral issues for young adults with cancer. Cancer. 2011; 117(10 Suppl): 2289-2294, doi: 10.1002/cncr.26056, indexed in Pubmed: 21523748.

6. Green CR, Hart-Johnson T. Cancer pain: an age-based analysis. Pain Med. 2010; 11(10): 1525-1536, doi: 10.1111/j. 1526-4637.2010.00957.x, indexed in Pubmed: 21199305.

7. Sugden C. Total pain: a multidisciplinary approach. Health and Social Care Chaplaincy. 2013; 4(2): 2-7, doi: 10.1558/hscc.v4i2.2.

8. Mehta A, Chan L. Understanding of the Concept of "Total Pain". Journal of Hospice \& Palliative Nursing. 2008; 10(1): 26-32, doi: 10.1097/01.njh.0000306714.50539.1a.

9. Syrjala KL, Jensen MP, Mendoza ME, et al. Psychological and behavioral approaches to cancer pain management. J Clin Oncol. 2014; 32(16): 1703-1711, doi: 10.1200/JCO.2013.54.4825, indexed in Pubmed: 24799497.
10. Silverman J, Kurtz S, Draper J. Skills for Communicating with Patients. 2016, doi: 10.1201/9781910227268.

11. Shindul-Rothschild J, Flanagan J, Stamp KD, et al. Beyond the Pain Scale: Provider Communication and Staffing Predictive of Patients' Satisfaction with Pain Control. Pain Manag Nurs. 2017; 18(6): 401-409, doi: 10.1016/j. pmn.2017.05.003, indexed in Pubmed: 28843634.

12. Reddy A, Hui D, Bruera E. A Successful Palliative Care Intervention for Cancer Pain Refractory to Intrathecal Analgesia. Journal of Pain and Symptom Management. 2012; 44(1): 124-130, doi: 10.1016/j.jpainsymman.2011.07.010.

13. Wachholtz AB, Fitch CE, Makowski S, et al. A Comprehensive Approach to the Patient at End of Life: Assessment of Multidimensional Suffering. South Med J. 2016; 109(4): 200-206, doi: 10.14423/SMJ.0000000000000439, indexed in Pubmed: 27043799.

14. Palliative TrR, Kongsgaard U, Kaasa S, et al. Palliative Treatment of Cancer-Related Pain [Internet]Editors, Kongsgaard U, Kasa S, Dale O, Ottesen S, Nordøy T, Hessling SE, von Hofacker S, Bruland ØS, Lyngstadaas A.

15. Panikulam A. Total pain management. Indian J Palliat Care. 2011; 17(Suppl): S68-S69, doi: 10.4103/0973-1075.76246, indexed in Pubmed: 21811375.

16. Brant J. Holistic Total Pain Management in Palliative Care: Cultural and Global Considerations. Palliative Medicine and Hospice Care - Open Journal. 2017; SE(1): S32-S38, doi: 10.17140/pmhcoj-se-1-108.

17. Silbermann M, Pitsillides B, Al-Alfi N, et al. Multidisciplinary care team for cancer patients and its implementation in several Middle Eastern countries. Ann Oncol. 2013; 24 Suppl 7: vii41-vii47, doi: 10.1093/annonc/mdt265, indexed in Pubmed: 24001762.

18. Wachholtz AB, Fitch CE, Makowski S, et al. A Comprehensive Approach to the Patient at End of Life: Assessment of Multidimensional Suffering. South Med J. 2016; 109(4): 200-206, doi: 10.14423/SMJ.0000000000000439, indexed in Pubmed: 27043799. 